\title{
HYOU1 Gene
}

National Cancer Institute

\section{Source}

National Cancer Institute. HYOU1 Gene. NCI Thesaurus. Code C20790.

This gene plays in the regulation of cellular response to ischemic stress conditions. 